University of Nebraska - Lincoln

DigitalCommons@University of Nebraska - Lincoln

Faculty Publications in the Biological Sciences

Papers in the Biological Sciences

10-2001

\title{
Diversity and Productivity in a Long-Term Grassland Experiment
}

\author{
David Tilman \\ University of Minnesota, St. Paul, tilman@umn.edu \\ Peter B. Reich \\ University of Minnesota, St. Paul \\ Johannes Knops \\ University of Nebraska - Lincoln, jknops@unl.edu \\ David A. Wedin \\ University of Nebraska - Lincoln, dwedin1@unl.edu \\ Troy Mielke \\ University of Minnesota, St. Paul \\ See next page for additional authors
}

Follow this and additional works at: https://digitalcommons.unl.edu/bioscifacpub

Part of the Life Sciences Commons

Tilman, David; Reich, Peter B.; Knops, Johannes; Wedin, David A.; Mielke, Troy; and Lehman, Clarence, "Diversity and Productivity in a Long-Term Grassland Experiment" (2001). Faculty Publications in the Biological Sciences. 151.

https://digitalcommons.unl.edu/bioscifacpub/151

This Article is brought to you for free and open access by the Papers in the Biological Sciences at DigitalCommons@University of Nebraska - Lincoln. It has been accepted for inclusion in Faculty Publications in the Biological Sciences by an authorized administrator of DigitalCommons@University of Nebraska - Lincoln. 


\section{Authors}

David Tilman, Peter B. Reich, Johannes Knops, David A. Wedin, Troy Mielke, and Clarence Lehman 
Published in Science Vol. 294. no. 5543 (October 26, 200 I), pp. 843-845; doi: I 0. I I 26/science. I06039 I Copyright (C) 200I American Association for the Advancement of Science. Used by permission.

Submitted March 5, 200I; accepted August 20, 200 I.

\title{
Diversity and Productivity in a Long-Term Grassland Experiment
}

\section{David Tilman, ${ }^{\text {* }}$ Peter B. Reich, ${ }^{2}$ Johannes Knops, ${ }^{3}$ David Wedin, ${ }^{4}$ Troy Mielke,' Clarence Lehman'}

\author{
I. Department of Ecology, Evolution and Behavior, University of Minnesota, St. Paul, MN 55 I08, USA. \\ 2. Department of Forest Resources, University of Minnesota, St. Paul, MN 55 I08, USA. \\ 3. School of Biological Sciences, University of Nebraska-Lincoln, Lincoln, NE 68588, USA. \\ 4. School of Natural Resource Sciences, University of Nebraska-Lincoln, Lincoln, NE 68583, USA. \\ Corresponding author — D.Tilman, email tilman@umn.edu
}

\begin{abstract}
Plant diversity and niche complementarity had progressively stronger effects on ecosystem functioning during a 7-year experiment, with 16-species plots attaining 2.7 times greater biomass than monocultures. Diversity effects were neither transients nor explained solely by a few productive or unviable species. Rather, many higher-diversity plots outperformed the best monoculture. These results help resolve debate over biodiversity and ecosystem functioning, show effects at higher than expected diversity levels, and demonstrate, for these ecosystems, that even the best-chosen monocultures cannot achieve greater productivity or carbon stores than higher-diversity sites.
\end{abstract}

Recent demonstrations that greater plant diversity can lead to greater productivity (1-5) have generated considerable debate (6-14). This has been fueled by uncertainty about which of many alternative hypotheses $(6,9,15-20)$ is operating in nature and about the number of species required to maintain ecosystem functioning $(6,7,12,14)$. We report results of a long-term experiment that allows tests of these alternative hypotheses.

It has been hypothesized that productivity may be greater at higher diversity because of "niche complementarity" among particular combinations of species and the greater chance of occurrence of such combinations at higher diversity (15-20). Niche complementarity, which results from interspecific differences in resource requirements and in spatial and temporal resource and habitat use, or from positive interactions (21), is predicted to allow stable multispecies coexistence and sustainably greater productivity at higher diversity $(17,18)$. Alternatively, it has been hypothesized that reported diversity effects might be short-lived transients caused solely by the presence of some species with high growth rates (6); be experimental artifacts resulting solely from species pools containing some lowviability species (6); or result from the most productive species being the best competitor $(6,9$, 17). These "sampling effects" all result from the greater chance of any given species being present at higher diversity and from dynamics that cause a single species to dominate and determine ecosystem functioning $(6,9,17,19)$.

Sampling and complementarity have different signatures $(6,9,12,17-20)$. Sampling ef fects limit the maximal productivity of higherdiversity plots to that of the best monoculture, giving an upper bound of variation in community performance that is independent of diversity. With niche complementarity, the upper bound increases with diversity because no monoculture is as productive as some combinations of two species and no combination of $N$ species is as productive as some combinations of $N+1$ species

In a 7-year experiment [(4), supplement A (22)], we controlled one component of diversity, the number of plant species, in 168 plots, each $9 \mathrm{~m}$ by $9 \mathrm{~m}$. We seeded the plots, in May 1994, to have $1,2,4,8$, or 16 species, with $39,35,29,30$, and 35 replicates, respectively. The species composition of each plot was chosen by random draw from a pool of 18 grassland perennials that included four C4 (warm-season) grasses, four C3 (cool-season) grasses, four legumes, four nonlegume forbs, and two woody species. All species occurred in monoculture, and all but three were in at least two monoculture plots, allowing comparison of responses of each species in monoculture to higher-diversity combinations of these same species. We do not use 76 additional plots that had functional group compositions drawn from an augmented species pool or 46 plots planted to 32 species (4) because the additional species were not grown in monoculture, and combining results from different species pools could introduce bias. We focus analyses on species number, because it was directly controlled, and functional group composition (23), because of its hypothesized importance. Other measures of diversity, includ- ing number of species per functional group and the presence or absence of species or functional groups, are highly correlated with species number and show similar responses.

In our grasslands, plant aboveground living biomass, because it is all produced within a growing season, is an index of primary productivity. In contrast, total biomass (aboveground plus belowground plant biomass) measures carbon accumulated in living tissues. Both aboveground and total biomass increased highly significantly with species number each year (Figure 1, A and B, and Table 1), and functional group composition explained a highly significant amount of the residual variation (Table 1). Moreover, when the effect of each variable was determined after controlling for effects of the other (type III regressions), effects of functional group composition predominated in the early years [as for $(24,25)]$, but species number had highly significant positive effects on both aboveground and total biomass by 1999 and 2000, showing the simultaneous importance of species number and functional group composition in the long-term (Table 1).

The initial saturating dependence of aboveground and total biomass on species number (Figure 1, A and B) became, by 2000, a linear increase for species number $\geq 2$. In 2000, 16-species plots had 22\% greater aboveground biomass total and 27\% greater total biomass than 8-species plots (both differences significant; $t$ tests: $P=0.018, P=0.002$, respectively). The dependence of biomass on species number and functional group composition became progressively stronger, explaining about one-third of variance in 1997 and two-thirds in 2000 (Table 1). This strengthening of the effect of diversity and the increasingly steep and linear trends (Figure 1, A and B) fail to support the hypothesis (6) that diversity effects were short-lived transients. Comparable and significant $(P<0.01)$ dependences of total and aboveground biomass on diversity and composition were observed when analyses used the actual number of planted species observed in each plot (Figure 1C) or the Shannon diversity index [supplement B (22)]

We tested the low-viability sampling hypothesis by identifying the five species that at tained least total biomass in monoculture in 2000 and excluding from analysis plots containing any combinations of just these species. Total biomass was still significantly dependent on species number and functional group composition in the remaining 131 plots [general linear model (GLM) type III regression: $F_{\text {OVERALL }}$ $=8.39, P<0.001 ; F_{\mathrm{DIV}}=11.6, F_{\mathrm{COMP}}=4.36$ ,$P<0.001$ for each]. Similar results occurred when we excluded from analysis of aboveground biomass plots containing any combinations of the five species with least aboveground biomass in monoculture (GLM type III regression: $F_{\text {OVER }}$ $\mathrm{ALL}=7.08, P<0.001 ; F_{\mathrm{DIV}}=10.6, P=0.0014$; $\left.F_{\mathrm{COMP}}=3.84, P<0.001\right)$. In another analysis, we excluded the 30 plots with the lowest total biomass in 2000 (total biomass $<400 \mathrm{~g} \mathrm{~m}^{-2}$ ). 
Species number and composition still had highly significant effects on total biomass in the remaining plots (GLM type III regression: $F_{\text {OVER- }}$ $\mathrm{ALL}=5.05, P<0.001 ; F_{\mathrm{DIV}}=12.3, P<0.001$; $\left.F_{\text {COMP }}=2.82, P<0.001\right)$. Similarly, when we excluded the 31 plots with lowest aboveground biomass $\left(<100 \mathrm{~g} \mathrm{~m}^{-2}\right)$ in 2000, effects of composition and species number remained highly significant (GLM type III regression: $F_{\text {OVER }}$ ${ }_{\mathrm{ALL}}=3.77, P<0.001 ; F_{\mathrm{DIV}}=10.5, P<0.0016$; $\left.F_{\text {COMP }}=2.28, P=0.0015\right)$. Similar results occurred with lower and higher cutoffs (including $50 \%$ higher) for aboveground and total biomass. In total, the dependence of biomass on species number and composition was not explained solely by sampling effects for a species pool containing some poorly performing species.

We tested the sampling hypothesis that the most productive species determined the effects of diversity $(6,9,17)$ by retaining in analyses of year 2000 results only plots containing at least one of the nine species with the highest monoculture total biomass in 2000. Total biomass remained significantly dependent on species number and functional group composition in these 145 plots, and in the subset of 95 plots that contained at least two of these nine species [type III regressions; supplement C (22)]. Similar results occurred for aboveground biomass in 2000 [supplement C (22)]. These analyses fail to support the sampling hypothesis. Another test comes from examining performance of higherdiversity plots relative to the best monoculture (Figure 2). In 1999 and 2000, many higher-diversity plots had greater aboveground and total biomass than the single best-performing monoculture (Figure 2). The percentage of such plots was an increasing function of diversity, on average for 1999 and 2000, with about half of the 16-species plots having greater aboveground or total biomass than the best monocultures (Figure 1D). The strength and repeatability of this increasing upper bound in both aboveground and total biomass support the importance of niche effects and refute the hypothesis that sampling effects were the sole explanation for the long-term effects of diversity. The coexistence of most species, with about 12 planted species per $2 \mathrm{~m}^{2}$ persisting in each 16-species plot (Figure 1C), further supports niche complementarity. However, in earlier years, such as 1997, few high-diversity plots had greater biomass than top monocultures, and the percentage was independent of species number (Figure 1D), which is consistent with the sampling hypothesis $(6,7,12)$.

The increasing importance of complementarity and the increasingly linear effects of species number raise another question. Did complementarity occur among most species-i.e., did most species contribute to increasing community biomass - or is there a smaller set of species with complementary interactions, with this set being increasingly likely to co-occur at higher diversity (19)?

We used analysis of variance (ANOVA) to determine the simultaneous effects of the
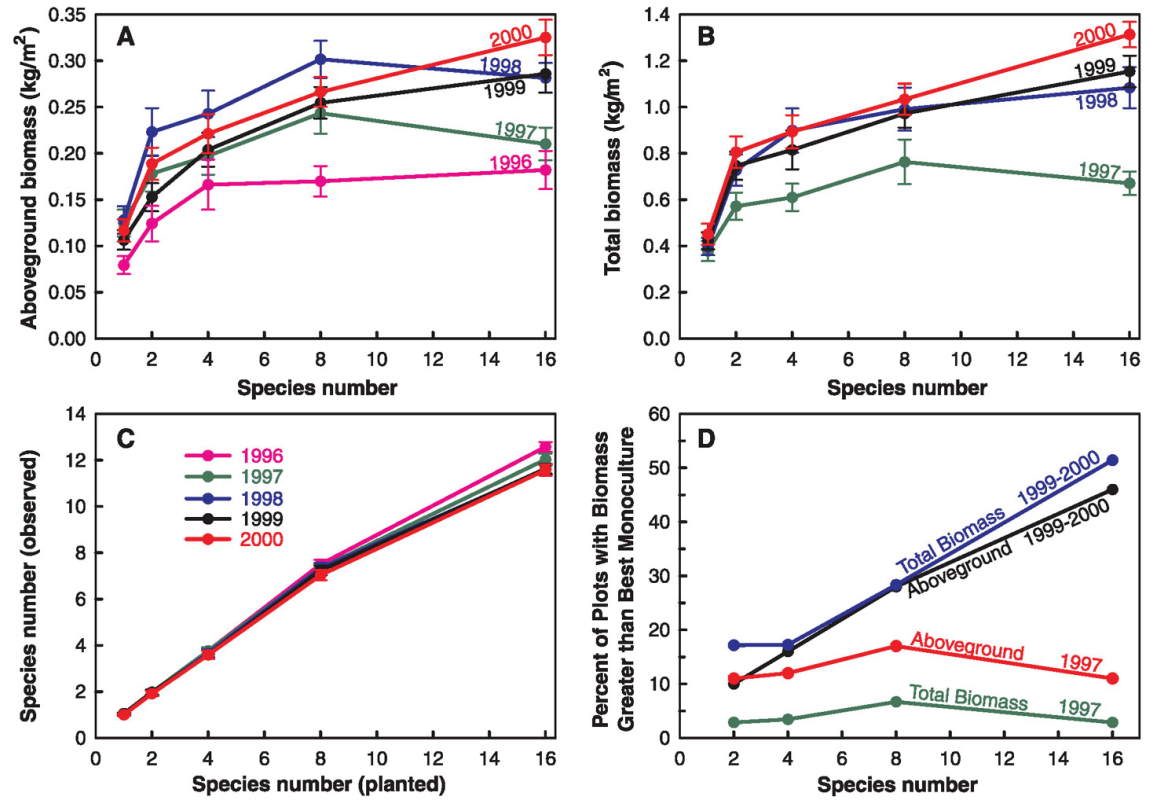

Figure I. The dependence of (A) plant aboveground biomass and (B) total biomass (aboveground plus belowground living plant mass) on the number of planted species. Data are shown as the mean \pm SE. (C) The relation between the number of species planted in a plot and the actual number (mean \pm SE) of planted species visually observed in a $2 \mathrm{~m}^{2}$ area of each plot. (D) The percentage of all plots of a given planted diversity level, on average for 1999 and 2000 combined, or on average for 1997, that had greater biomass than the single monoculture plot with the greatest biomass.
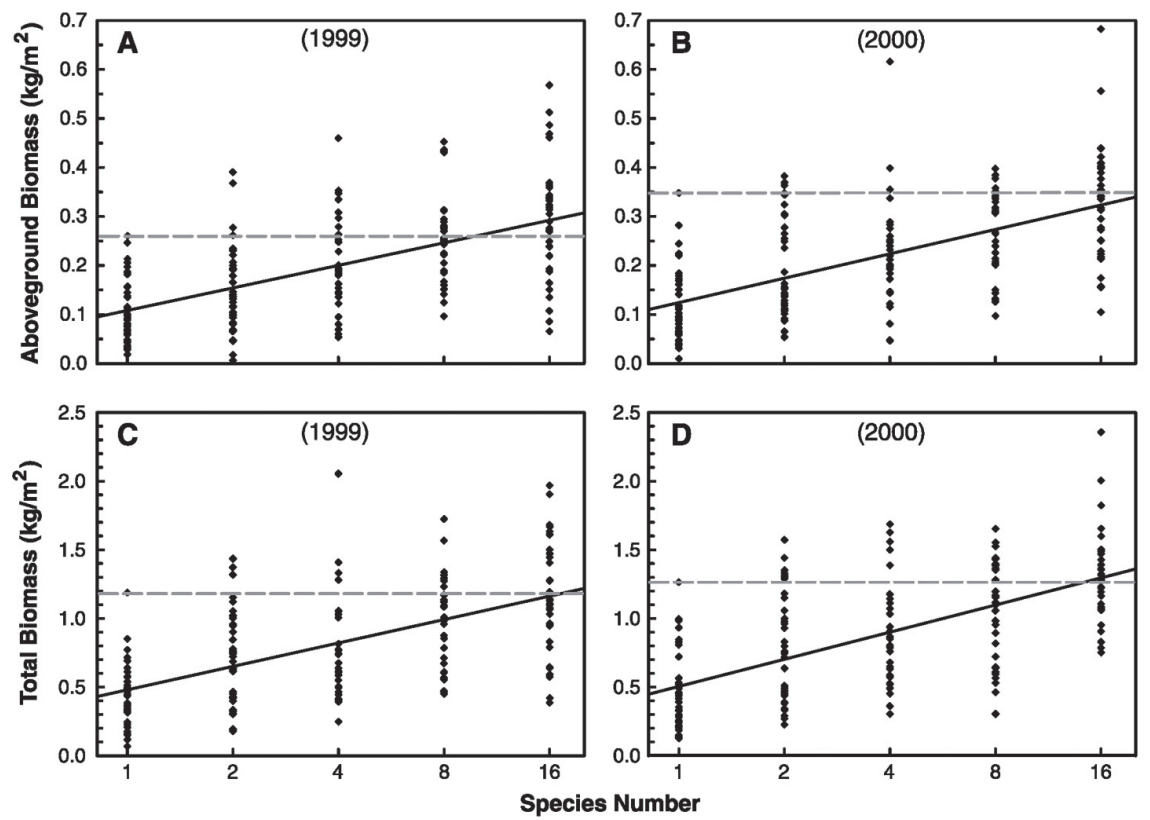

Figure 2. The dependence of aboveground ( $\mathbf{A}$ and $\mathbf{B}$ ) and of total (C and $\mathbf{D})$ biomass of each plot on planted species number for 1999 and 2000. The broken line shows the biomass of the top monoculture for a given year. The solid line is a regression of biomass on the logarithm of species number. Logarithm of species number was used in the figure because it gave slightly better fits, but was not used in Table I because it often gave slightly lower $R^{2}$ values than species number.

presence or absence of each species (entered as main effects) on aboveground or total biomass (one test per year, with 4 years for total biomass, 5 years for aboveground biomass). Three or four species had significant $(P<0.05)$ positive effects on aboveground or total biomass in most years. Among legumes, Lupinus perennis had significant effects in all nine tests, Lespedeza capitata in six tests, and Petalostemum purpureum in two tests. Schizachyrium scoparium and Sorghastrum nutans, both C4 grasses, were significant in five tests each. These are five of the 
Table I. Analyses, using general linear models, of the effects of number of planted species (continuous variable; entered first using type I SS) and of functional group composition (categorical variable; entered second) on total biomass and on aboveground biomass, showing results for each year when measured. $N=168$. Overall model $\mathrm{df}=28$ and error $\mathrm{df}=139$. Species number $\mathrm{df}=\mathrm{I}$, composition $\mathrm{df}=27$. The last columns show type III effects of species number (entered second, after functional group composition).

\begin{tabular}{|c|c|c|c|c|c|c|c|c|c|c|}
\hline \multirow[b]{2}{*}{ Variable analyzed } & \multirow[b]{2}{*}{ Year } & \multicolumn{3}{|c|}{ Overall } & \multicolumn{2}{|c|}{$\begin{array}{l}\text { Species number } \\
\text { (entered first) }\end{array}$} & \multicolumn{2}{|c|}{$\begin{array}{l}\text { Functional group comp. } \\
\text { (entered second) }\end{array}$} & \multicolumn{2}{|c|}{$\begin{array}{l}\text { Species number } \\
\text { (entered second) }\end{array}$} \\
\hline & & $R^{2}$ & $F$ value & $P$ & $F$ value & $P$ & $F$ value & $P$ & $F$ value & $P$ \\
\hline Total biomass & 1997 & 0.32 & 2.26 & 0.001 & 9.80 & 0.002 & 2.06 & 0.004 & 3.88 & 0.051 \\
\hline Total biomass & 1998 & 0.47 & 4.37 & $<0.001$ & 43.8 & $<0.001$ & 2.91 & $<0.001$ & 2.38 & 0.13 \\
\hline Total biomass & 1999 & 0.60 & 7.31 & $<0.001$ & 94.2 & $<0.001$ & 4.09 & $<0.001$ & 7.11 & 0.009 \\
\hline Total biomass & 2000 & 0.68 & 10.5 & $<0.001$ & 152. & $<0.001$ & 5.27 & $<0.001$ & 12.3 & $<0.001$ \\
\hline Aboveground biomass & 1996 & 0.41 & 3.28 & $<0.001$ & 15.5 & $<0.001$ & 2.83 & $<0.001$ & 3.80 & 0.053 \\
\hline Aboveground biomass & 1997 & 0.39 & 3.02 & $<0.001$ & 12.3 & $<0.001$ & 2.60 & $<0.001$ & 0.52 & 0.47 \\
\hline Aboveground biomass & 1998 & 0.49 & 4.80 & $<0.001$ & 31.8 & $<0.001$ & 3.81 & $<0.001$ & 2.56 & 0.11 \\
\hline Aboveground biomass & 1999 & 0.56 & 6.27 & $<0.001$ & 90.7 & $<0.001$ & 3.15 & $<0.001$ & 14.9 & $<0.001$ \\
\hline Aboveground biomass & 2000 & 0.61 & 7.80 & $<0.001$ & III. & $<0.001$ & 3.97 & $<0.001$ & 10.7 & $<0.001$ \\
\hline
\end{tabular}

six most abundant species in mixtures. A rarer forb also had a significant effect. Similarly, when plots were characterized by the presence or absence of functional groups in ANOVAs, in 2000 there were significant positive effects of legumes $(P<0.001)$, forbs $(P<0.05)$, and $\mathrm{C} 4$ grasses $(P<0.01)$ on aboveground biomass, and significant positive effects of legumes $(P<0.001)$ and $\mathrm{C} 4$ grasses $(P<0.001)$ on total biomass. For aboveground biomass, only the legume $\times \mathrm{C} 4$ grass interaction was significant $(P<0.05)$, and it was positive. For total biomass, the legume $\times \mathrm{C} 4$ grass interaction was marginally significant $(P=0.068)$ and biased toward positive (26), suggesting complementarity or facilitation among legumes and $\mathrm{C} 4$ grasses (4). However, even after controlling for the presence or absence of all functional groups, there were positive $(P<0.02)$ effects of species number on both aboveground and total biomass in 2000, indicating that biomass also depended on species number rather than on just the presence of functional groups.

Although these analyses suggest that the presence of about five dominant species might explain much of the effects of diversity, there may be small but additive effects of rarer species. To test this possibility, we ranked all species on the basis of their abundance (percentage cover) in 16-species plots in 2000, and created 17 new diversity indices. Each index states how many of the $N$ most abundant species $(N=2,3, \ldots 18)$ had been planted in each plot. We then determined which diversity index (log transformed) explained the most variance in aboveground or total biomass in 2000. Aboveground biomass was most dependent on how many of the 9 to 13 most abundant species were planted in each plot [supplement D (22)], showing that many rarer species contributed detectably to aboveground biomass. However, total biomass in 2000 was most dependent on how many of the four most abundant species were planted [supplement D (22)], likely because three of these four are $\mathrm{C} 4$ grasses, the species that accumulate the greatest root mass.

In summary, diversity effects were neither transients, nor explained in the long-term solely by other sampling-effect hypotheses, nor solely by the presence of legumes on a low- $N$ soil. Rather, niche complementarity contributed significantly. Plant species number [as in (1-5, 20, 21)] and functional group composition [as in (4, $5,24,25)]$ became simultaneously and approximately equally important in our long-term experiment. Compared with the average of the single best species in monoculture, our 16-species plots had 39\% greater aboveground biomass and $42 \%$ greater total biomass on average for 1999 and 2000. Moreover, 16-species plots in 1999 and 2000 had 2.7 to 2.9 times greater aboveground and total biomass than the average for all species in monoculture (Figure 1A). The nonsaturating increase in aboveground biomass with diversity likely reflects niche effects among about 9 to 13 species and their greater chance of co-occurrence at higher diversity (19), whereas such effects among about four species seem to account for total biomass responses.

The demonstration that diversity effects strengthened through time and were not the result solely of sampling effects or functional group composition should resolve aspects of the biodiversity debate (6-14). Moreover, our results suggest, for ecosystems in which niche complementarity occurs, that even with the wisest choices, monocultures may be less productive and accumulate less living carbon than many higher-diversity species combinations. Our results show that ecosystem processes are simultaneously influenced by diversity and composition, but longterm work in additional ecosystems is needed to determine the generality of our results, to better understand the effects of nonrandom community assembly and disassembly, and to better determine the implications of biodiversity for ecosystem management.

\section{References and Notes}

I. S. Naeem, L. Thompson, S. Lawler, J. Lawton, R.Woodfin, Nature 368, 734 (1994)

2. Philos. Trans. R. Soc. London Ser. B 347, 249 (1995)

3. D. Tilman, D. Wedin, J. Knops, Nature 379, 718 (1996)

4. D. Tilman, J. Knops, D. Wedin, P. Reich, M.
Ritchie, E. Siemann, Science 277, I 300 (1997)

5. A. Hector, et al., Science 286, I I 23 (I999)

6. M. Huston, Oecologia I I 0, 449 (1997)

7. J. Grime, Science 277, I260 (1997)

8. E. Garnier, M.-L. Navas, M. Austin, J. Lilley, R. Gifford, Acta Oecol. 18, 657 (1997)

9. L.Aarssen, Oikos 80, 183 (1997)

10. J. Hodgson, K. Thompson, P. Wilson, A. Bogaard, Funct. Ecol. 12, 843 (1998)

II. D.Wardle, Oikos 87, 403 (I999)

12. D. Wardle, et al., Bull. Ecol. Soc. Am. 8I, 235 (2000) .

13. J. Kaiser, Science 289, 1282 (2000)

14. L. Guterman, The Chronicle of Higher Education (13 October 2000), A24.

15. J. Vandermeer, The Ecology of Intercropping (Cambridge Univ. Press, New York, 1989).

16. M. Swift, J. Anderson, in Biodiversity and Ecosystem Function, E.-D. Schulze, H. Mooney, Eds. (Springer Verlag, Berlin, Germany, 1993), Pp. |5-4|.

17. D. Tilman, C. Lehman, K. Thomson, Proc. Natl. Acad. Sci. U.S.A. 94, I857 (1997)

18. C. Lehman and D. Tilman, Am. Nat. I56, 534 (2000)

19. M. Loreau, Oikos 9 I, 3 (2000) .

20. M. Loreau and A. Hector, Nature 4I2, 72 (200I)

2I. C. P. H. Mulder, D. D. Uliassi, D. F. Doak, Proc. Natl.Acad. Sci. U.S.A. 98, 6704 (200I)

22. Supplementary material follows the "References and Notes"; it is also available on Science Online at www.sciencemag.org/cgi/ content/full/294/5543/843/DCl.

23. There are $3 \mathrm{I}$ possible combinations of five functional groups taken $I$ to 5 at a time $\left(2^{5}-1\right)$, of which 28 combinations occurred in the 168 plots. The combination that occurred in a plot is referred to as its functional group composition.

24. D. Hooper and P.Vitousek, Science 277, 1302 (1997)

25. ,Ecol. Monogr. 68, I2I (1998) .

26. Adjusted mean total biomass in 2000 , from ANOVA: $342 \mathrm{~g} \mathrm{~m}^{-2}$ for plots with neither C4 grasses nor legumes; $832 \mathrm{~g} \mathrm{~m}^{-2}$ for C4's but not legumes; $564 \mathrm{~g} \mathrm{~m}^{-2}$ for legumes but not C4's; $1234 \mathrm{~g} \mathrm{~m}^{-2}$ for both.

27. We thank the National Science Foundation (NSF/DEB 0080382 and NSF/DEB 9629566) and the Andrew Mellon Foundation for support; J. Fargione, S. Pacala, S. Levin, A. Dobson, and J. Reichman for comments; and N. Larson, C. Bristow, and L. Johnson for assistance. 


\section{Supplementary Material}

\section{Supplement A.}

Experimental Protocol.

A field at Cedar Creek Natural History Area, Minnesota, was herbicided and burned in August, 1993, had 6-8 cm of soil removed to reduce the seed bank, was plowed and harrowed, then divided into plots of which 168 form this experiment. All plots received, in total, 10 $\mathrm{g} \mathrm{m}^{-2}$ of seed in May 1994 and $5 \mathrm{~g} \mathrm{~m}^{-2}$ in May 1995, with seed mass divided equally among species. Two species that did not germinate in 1994 were replaced with different species in the same functional groups in the 1995 , with their seeding proportionate to $10 \mathrm{~g} \mathrm{~m}^{-2}$. Three species (Elymus canadensis, Poa pratensis, Panicum virgatum) did not establish in one of their two original monocultures, even after reseeding, and these three plots were abandoned after 1996. Plots were initially $13 \mathrm{~m} \times 13 \mathrm{~m}$, and reduced to $9 \mathrm{~m} \times 9 \mathrm{~m}$ in 1998 by mown walkways. Treatments were maintained by weeding 3 or 4 times/year. Selective herbicides were also used through 1997. Plots were burned annually in the spring before growth began. Plots were sampled in mid-August for aboveground living plant biomass by clipping, drying, and weighing four $0.1 \times 3.0 \mathrm{~m}$ vegetation strips per plot from 1996 through 1999, and eight strips per plot in 2000. Only non-mown areas were sampled. Different areas were sampled each year. Beginning in 1997, root biomass was sampled immediately after clipping by collecting three $5 \mathrm{~cm}$ diameter x $30 \mathrm{~cm}$ deep cores per clipped strip. Roots were washed free of soil, sorted from other organic material, dried and weighed. The sum of root mass and aboveground mass, on an aerial basis, is called total plant biomass, a measure of total living carbon.

\section{Supplement B.}

Effects of observed plant diversity on total and aboveground biomass in 2000.

Two indices of plant diversity are used. The first index, "observed species number," is the number of planted species observed in one or more of four $0.5 \mathrm{~m}^{2}$ quadrats within each plot. The second, “effective species richness," is $\mathrm{e}^{\mathrm{H}}$, where $\mathrm{H}^{\prime}$ is the Shannon diversity index based on abundances (percent cover) of planted species. Analyses, using general linear models, determined effects of plant diversity (continuous variable; entered first using Type I SS) and of functional group composition (categorical variable; entered second) on total biomass and on aboveground biomass. $\mathrm{N}=168$. Overall model d.f. $=28$ and error d.f. $=139$, with plant diversity d.f. $=1$ and composition d.f. $=27$. The last columns show similar analyses, but with plant diversity entered second, after composition (i.e., Type III regressions).

\begin{tabular}{|c|c|c|c|c|c|c|c|c|c|c|}
\hline \multirow[b]{2}{*}{ Variable Analyzed } & \multirow[b]{2}{*}{ Year } & \multicolumn{3}{|c|}{ Overall } & \multicolumn{2}{|c|}{$\begin{array}{l}\text { Plant } \\
\text { Diversity } \\
\text { (entered I }{ }^{\text {st }} \text { ) }\end{array}$} & \multicolumn{2}{|c|}{$\begin{array}{l}\text { Functional Group } \\
\text { Comp. } \\
\text { (entered } 2^{\text {nd }} \text { ) }\end{array}$} & \multicolumn{2}{|c|}{$\begin{array}{l}\text { Plant } \\
\text { Diversity } \\
\left(\text { entered } 2^{\text {nd }}\right)\end{array}$} \\
\hline & & $R^{2}$ & F value & $P$ & F value & $P$ & $F$ value & $P$ & F value & $P$ \\
\hline \multicolumn{11}{|c|}{ Observed Species Number: } \\
\hline $\begin{array}{l}\text { Total Biomass } \\
\text { Aboveground Biomass }\end{array}$ & $\begin{array}{l}2000 \\
2000\end{array}$ & $\begin{array}{l}0.68 \\
0.63\end{array}$ & $\begin{array}{l}10.6 \\
8.40\end{array}$ & $<0.001$ td="td">133. & 157. & 3.78 & 5.20 & 17.7 & 13.3 & \\
\hline \multicolumn{11}{|c|}{ Effective Species Richness $\left(\mathrm{e}^{\mathrm{H}^{\prime}}\right)$ : } \\
\hline $\begin{array}{l}\text { Total Biomass } \\
\text { Aboveground Biomass }\end{array}$ & $\begin{array}{l}2000 \\
2000\end{array}$ & $\begin{array}{l}0.66 \\
0.61\end{array}$ & $\begin{array}{l}9.53 \\
7.73\end{array}$ & $<0.001$ td="td">132. & 136. & 3.11 & 4.84 & 14.0 & 7.82 & 0.006 \\
\hline
\end{tabular}




\section{Supplement C.}

GLM Type III regressions (each variable considered after controlling for the other variable) for effects of species number and functional group composition on total biomass and on aboveground biomass in 2000, for two different subsets of plots. The first subset consists of all plots containing at least 1 of the 9 species with highest total or aboveground biomass in monoculture in 2000. The second subset consists of plots containing at least 2 of these top 9 species.

\begin{tabular}{|c|c|c|c|c|c|c|c|}
\hline \multirow[b]{2}{*}{ Variable Analyzed } & \multicolumn{3}{|c|}{ Overall } & \multicolumn{2}{|c|}{ Plant Diversity } & \multicolumn{2}{|c|}{ Functional Group } \\
\hline & $\mathrm{N}$ & F-Value & $\mathrm{P}$ & F-Value & $\mathrm{P}$ & F-Value & $\mathrm{P}$ \\
\hline \multicolumn{8}{|c|}{ At Least I of 9 Top Species: } \\
\hline $\begin{array}{l}\text { Total Biomass } \\
\text { Aboveground Biomass }\end{array}$ & $\begin{array}{l}145 \\
140\end{array}$ & $\begin{array}{l}6.08 \\
4.43\end{array}$ & & $\begin{array}{l}10.5 \\
8.85\end{array}$ & $\begin{array}{l}0.002 \\
0.004\end{array}$ & $\begin{array}{l}3.33 \\
2.72\end{array}$ & \\
\hline \multicolumn{8}{|c|}{ At Least 2 of 9 Top Species: } \\
\hline $\begin{array}{l}\text { Total Biomass } \\
\text { Aboveground Biomass }\end{array}$ & $\begin{array}{l}95 \\
88\end{array}$ & $\begin{array}{l}3.47 \\
2.34\end{array}$ & 0.005 & $\begin{array}{l}11.9 \\
5.04\end{array}$ & 0.028 & $\begin{array}{l}2.67 \\
1.87\end{array}$ & $\begin{array}{l}0.002 \\
0.030\end{array}$ \\
\hline
\end{tabular}

\section{Supplement D.}

Goodness of fit, as estimated by $\mathrm{R}^{2}$ values, for regressions of total biomass in 2000 on the log of the number of the $\mathrm{N}$ top species that were present in each plot. For instance, when $\mathrm{N}=4$, the four species with the greatest percent cover in 2000 in the 16 -species plots were considered. These four species were Schizachyrium scoparium, Lupinus perennis, Sorghastrum nutans and Andropogon gerardi. For each plot, we determined how many of these four species had been planted in the plot, and used this as a diversity index. Log [Diversity Index +1 ] was then used as the independent variable in a regression in which total biomass in 2000 was the dependent variable. Such regressions were repeated for the other diversity indices (values of $\mathrm{N}$, number of top species considered, ranging from 2 to 18 ). Web fig. 1 shows that $\mathrm{N}=4$ gave the best fit for total biomass.

Similar analyses were performed, but using aboveground biomass in 2000 as the dependent variable in a series of regressions. Web fig. 2 shows that the highest $\mathrm{R}^{2}$ value occurred for $\mathrm{N}=9$, i.e., when the number of the 9 most abundant species that were present in each plot was the independent variable. The next highest $R^{2}$ value occurred for $N=13$. The fitted curve had its peak at $N=11$. Each value of $N$ from 7 to 15 had a higher $\mathrm{R}^{2}$ value than any $\mathrm{N} \leq 6$.

$\mathrm{R}^{2}$ for Total Biomass By N of Log (Top N Species)
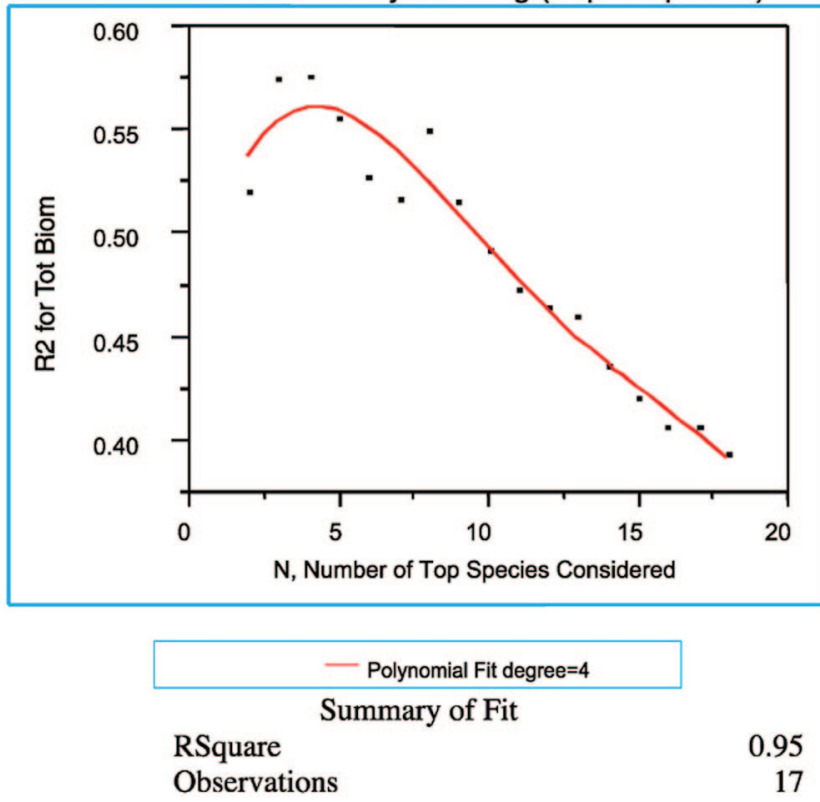

Supplemental Figure I. Dependence of $\mathrm{R}^{2}$ in Total Biomass on Number of Top Species Considered

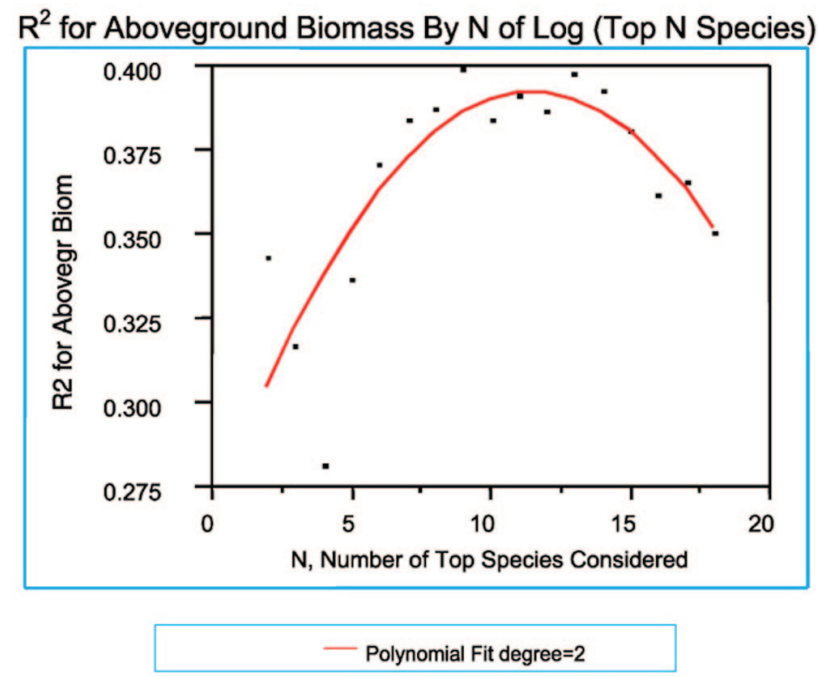

Polynomial Fit degree=2 Summary of Fit

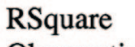

0.66

Observations

17

Supplemental Figure 2. Dependence of $R^{2}$ in Aboveground Biomass on Number of Top Species Considered 